IZA DP No. 8097

Trust-Based Work-Time and Product Improvements: Evidence from Firm Level Data

Olivier Godart Holger Görg Aoife Hanley

April 2014 


\title{
Trust-Based Work-Time and Product Improvements: Evidence from Firm Level Data
}

\author{
Olivier Godart \\ Kiel Institute for the World Economy \\ and University of Kiel \\ Holger Görg \\ Kiel Institute for the World Economy, \\ University of Kiel and IZA \\ Aoife Hanley \\ Kiel Institute for the World Economy \\ and University of Kiel
}

Discussion Paper No. 8097

April 2014

IZA

P.O. Box 7240

53072 Bonn

Germany

Phone: +49-228-3894-0

Fax: +49-228-3894-180

E-mail: iza@iza.org

Any opinions expressed here are those of the author(s) and not those of IZA. Research published in this series may include views on policy, but the institute itself takes no institutional policy positions. The IZA research network is committed to the IZA Guiding Principles of Research Integrity.

The Institute for the Study of Labor (IZA) in Bonn is a local and virtual international research center and a place of communication between science, politics and business. IZA is an independent nonprofit organization supported by Deutsche Post Foundation. The center is associated with the University of Bonn and offers a stimulating research environment through its international network, workshops and conferences, data service, project support, research visits and doctoral program. IZA engages in (i) original and internationally competitive research in all fields of labor economics, (ii) development of policy concepts, and (iii) dissemination of research results and concepts to the interested public.

IZA Discussion Papers often represent preliminary work and are circulated to encourage discussion. Citation of such a paper should account for its provisional character. A revised version may be available directly from the author. 
IZA Discussion Paper No. 8097

April 2014

\section{ABSTRACT \\ Trust-Based Work-Time and Product Improvements: Evidence from Firm Level Data}

We explore whether the introduction of trust based working hours is related to the subsequent innovation performance of firms. Employing a panel data set of over 5,000 German establishments, we implement a propensity score matching approach where we only consider firms that did not use trust based work contracts initially. Our results show that firms which adopt such contracts tend to be between 11 to 14 percent more likely to improve products. These results hold when we control for another form of flexible time work arrangements, namely working time accounts. Thus, the positive relationship between the adoption of trust based working hours and innovation seems to be driven by the degree of control and self-management over working days, rather than by merely allowing time flexibility.

JEL Classification: M54, M12

Keywords: $\quad$ trust based work time, innovation, firm performance

Corresponding author:

Holger Görg

Kiel Institute for the World Economy

Hindenburgufer 66

24105 Kiel

Germany

E-mail: holger.goerg@ifw-kiel.de 


\section{Introduction}

The organization of work has changed dramatically over the last few decades. Decision making has become more decentralized and 'flatter', workers tend to be engaged in multiple tasks rather than one single task, and the rigidly regulated working time has in many cases been abandoned (e.g. Brown et al., 2009). It is this latter issue that this paper is concerned with. Especially in recent years, flexible working hours systems have become an attractive human resource management option for numerous firms around the world. For example, 36 percent of employees were entitled to some form of flexible working hours plan in Germany in 2010 (German Statistical Office, 2012) while the share of employees with flexible work schedules in the US was about 25 percent in 2004 (Bureau of Labor Statistics, 2005).

Today, a firm wishing to set up flexible working time arrangements has to decide how much freedom over the work schedule to give to its employees. It might on one extreme give up only a limited amount of control - purely over working time - to employees by allowing employees to decide about their starting and finishing times. In return, employees would have to agree to work for a predefined number of hours each day. This form of flexible time arrangement is often called 'flexitime'. ${ }^{1}$ Another alternative, on the other extreme, would be to shift completely away from the classic five-day, 9 to 5, 40-hour week. Employees would now be free to adjust their time schedule as they wish. The latter arrangement would be subject to the employee's work function being covered in the employee's absence or subject to the employee achieving a predetermined output.

This form of flexible and self-managed work has grown in importance over the last decade and is known as 'trust based working hours'. In contrast to flexitime, the trust based working hours arrangement, implies a step towards increased employee self-management and autonomy. It is particularly common in Germany, where a German think tank (Institut der Deutschen Wirtschaft, 2010) found that roughly half of all firms surveyed used some variant of the so-called 'Vertrauensarbeitszeit' (trust based working hours), hereafter referred to as

\footnotetext{
${ }^{1}$ Beside these extremes, a range of working hours arrangements between employers and employees exist. The most prominent is the working time account, which is a credit/debit time accounting system, in which overtime (undertime) is carried over as a credit (debit) balance. The time account must be balanced after a predetermined period of time. If this period of time is one day, then it is similar to what we defined as flexitime. Most commonly time accounts have to be balanced after 6 months to two years.
} 
VAZ. They also find that the number of firms that implement VAZ nearly doubled since 2003.

Moreover, Germany has a large number of internationally competitive export oriented firms which rely heavily on product design and the novelty and quality of their products. As such, innovation provides a strong impetus to the Germany economy - as in many other economies where firms compete internationally. The purpose of our paper is to examine whether there is an 'innovation premium' associated with trust based work contracts. This question is motivated by economic theory (reviewed in the next section) which argues that such a work arrangement may be most efficient if production takes place in an uncertain environment and innovation activity is characterized by such uncertainty. Moreover, the management and psychology literatures argue and support the conclusion that trust based working time stimulates employee creativity. Accordingly, trust based working time is predicted to impact positively on creative activities e.g. innovation. We put these ideas to a systematic empirical test, using establishment level data for a large number of businesses in Germany.

From a policy perspective our analysis comes at an opportune time, as recently many politicians and practitioners are reassessing the benefits of work practices, which impact to a greater or lesser degree on individuals' work-life balance. Think of 'home office' as one example of VAZ which is often regarded as leading to conflicts between work and private life. Such concerns have recently led the former German Minister for Labour, Ms Ursula von der Leyen, to call for a halt of work practices that blur the boundaries between the workplace and home. ${ }^{2}$

This paper explores whether the introduction of trust based working hours is related to the subsequent innovation performance of firms. We employ a panel data set of over 5,000 German establishments to investigate this trust based innovation premium to firms which adopt trust-based working rules. The analysis exploits information on two cohorts of firms that adopted trust based working hours in 2008 and 2010, respectively, and compares their subsequent innovation performance to that of a control group of firms which are similar in terms of characteristics in the 'pre-adoption' period but which did not adopt trust based working hours.

\footnotetext{
' See the German business daily Handelsblatt: 'No E-mails at the Weekend' (Keine Emails am Wochenende)', 05.02.20
} 
To this purpose, we implement a propensity score matching approach where we only consider firms that did not use trust based work contracts initially. We estimate firms' propensities to adopt VAZ within a given period. Based on this propensity, we compare the innovation performance of firms that actually did adopt VAZ to those firms that are similar in terms of the propensity score but that did not choose to do so. This gives us an estimate of the average treatment effect on the treated which we interpret as the causal effect of adopting VAZ on innovative activity in a firm. We are, to the best of our knowledge, the first to carry out such a large scale empirical analysis of the potential causal effect of VAZ on innovation performance of firms. $^{3}$

Our results show that there is indeed an innovation premium to the use of VAZ. Firms which adopt trust-based work rules tend to be between 11 to 14 percent more likely to report innovative activity (in the sense of introducing new or improving existing products). We arrive at this estimate having first controlled for the propensity that firms become VAZ Adopters or remain as non-Adopters in the first place. The results for a simple OLS estimation are broadly similar. There the innovation premium is estimated at between 9 and 13 percent. These results hold even when we control for another form of flexible time work arrangements within firms, namely working time accounts. Thus, the positive relationship between the adoption of trust based working hours and innovation seems to be driven by the degree of control and self-management over working days that are transferred to employees, rather than by merely allowing time flexibility.

The rest of the paper is structured in the following way: we provide some initial background related to our research question in Section 2. We next describe our data. This is followed by an extended section which describes how we set-up the analysis to investigate differences between firms which adopt trust-based work rules and those which do not (VAZ Adopters vs. non Adopters). In that section we also report the results for our efforts to balance both groups. We also report the results for our core estimations as well as robustness tests. We conclude with a final section which summarizes our results and outlines the possible policy implications.

\section{Background}

\footnotetext{
${ }^{3}$ The paper most closely related to ours is Beckmann and Hegedüs (2011), which we discuss in Section 2. They report that firms with trust based hours have higher profitability and returns to sales net of employment costs.
} 
In the 'traditional' economics literature, the concept of employer-employee trust plays a special role when firms face rapidly changing environments. Here the information needed to modify products or production techniques grows exponentially. When the environment in which firms operate is highly uncertain, the problem of how best to assign tasks and decisionmaking authority is not trivial. This was recognised by Knight (1921) who stated that

\begin{abstract}
"When uncertainty is present, and the task of deciding what to do and how to do it takes ascendancy over that of execution, the internal organization of the productive groups is no longer a matter of indifference or a mechanical detail” (p. 268)
\end{abstract}

Following Dessein and Santos (2006), firms can deal with changing environments - i.e. uncertainty about product design, product functionality or product demand - in two ways: they can get employees to stick to a pre-arranged plan or, alternatively, firms can allow employees the autonomy to make changes in the plan as new knowledge (only observed to them) becomes available. In the latter case, employees are more autonomous, are responsible for several tasks and are best able to adapt to information flows that comes with improvements in communication technology. This theoretical view corresponds broadly with our concept of trust-based work arrangements, VAZ. Dessein and Santos (2006) show in their model that such a mode of organization is optimal when the environment is uncertain.

The way in which innovation is achieved by firms is subject to much uncertainty. We argue, therefore, that our measure of VAZ adoption, allows us to empirically capture some of the theoretical concepts which are described in Dessein and Santos (2006). When uncertainty is present, as is the case for innovation activity, it may be more efficient for firms to choose VAZ as this can provide workers with the flexibility and autonomy to tailor their actions to the local conditions and new information, rather than let them stick to a pre-arranged plan (the traditional management perspective). Hence, we would expect that the adoption of VAZ practices which increase the amount of worker flexibility should be associated positively with a firm's innovation capability.

Complementing this 'traditional' economics view, we may also appeal to other literatures to justify our research question. Research in psychology and management science (e.g., Scott and Bruce, 1994, Amabile and Mueller, 2008) argues forcefully that trust-based work arrangements are likely to foster creativity of workers. This is because such work practices enhance the intrinsic motivation of workers by making the work more satisfying and more 
enjoyable. Moreover trust-based work practices may be more conductive for the development of new ideas. This happens when organizational obstacles that may impede creativity are dismantled. Examples of such organizational obstacles include excessive time pressure and onerous reporting requirements. Hence, there is a strong expectation that such trust-based work arrangements, through fostering creativity of workers, also enhance a firm's innovation activity.

Yet, in most of the firm level research on innovation, such aspects are not considered. We are, to the best of our knowledge, the first to investigate this issue in detail. ${ }^{4}$ In our data, we can identify whether or not firms use trust-based employment contracts. Exploiting the time dimension in our data, we can examine innovation outcomes for VAZ Adopter and nonAdopter firms - where adoption implies the implementation of trust-based rules in time $\mathrm{t}-1$ and innovation outcomes are measured for time $t+1$.

Our paper brings together two literatures. First, we position our analysis within the recent literature on HR management practices and firm performance (e.g., Bloom and van Reenen, 2010). In this regard, a number of recent studies using quantitative methods reinforce the idea that flextime and productivity are positively correlated (Beauregard and Henry, 2009; Stavrou, 2005; Shepard III et. al. 1996; Konrad and Mangel 2000). A similar relationship is supported by Bloom et al. (2011) in the context of a study of work-life balance (WLB) measures on productivity in four countries. ${ }^{5}$

We look at one particular aspect of HR management, and consider a very specific channel through which such HR practices may impact on innovative activity through trust based working arrangements. To the best of our knowledge, this has not been done in the literature thus far. Within this broader literature, there are also a few papers focusing on the concept of 'trust' and its relationship with firm performance outcomes (productivity and profitability). For example, Bloom et al. (2013), recently collected data on 'trust' from managers in 12 countries. They showed that countries with high bilateral trust (e.g. Canadian managers from

\footnotetext{
${ }^{4}$ There is, however, a related literature that looks at time flexibility at the workplace and innovation (e.g., Zhou et al., 2011, Arvanitis, 2005). As pointed out above, our concept of a trust-based work arrangement is different, as it does not merely consider the work time but the whole arrangement of the tasks to be carried out. Hence, this is a much better intrinsic motivator than merely allowing flexi-time. We do, however, in the empirical analysis control for the presence of work arrangements that allow time flexibility in order to identify the effect of trustbased work arrangements on firms' innovation activities.

${ }^{5}$ However their main finding is that better WLB measures (including flexitime) are difficult to isolate from better human resource management practices in general when related to productivity.
} 
Protestant Anglo-Saxon tradition tend to trust employees in a Swedish affiliate due to their shared religious tradition) showed higher decentralization, i.e., a greater willingness to delegate decision making to subordinates in the firm. ${ }^{6}$ We probe deeper into another aspect of 'trust', based on work practices.

Secondly, in our analysis, we extend the firm level literature on innovation (see e.g. Aghion et al., 2005)). This firm-level innovation literature generally considers firm characteristics such as size or age, and factors external to the firm (such as the level of competition). We, by contrast, focus on the organizational mechanisms within a firm that may stimulate innovation.

None of the studies reviewed here so far deals directly with the focus of our study - the adoption of trust-based work practices. An exception is a recent study by Beckmann and Hegedüs (2011) which, similar to our work, examines the German VAZ. Using the 2006 wave of the German IAB data set, they focus on the link between VAZ and firm productivity. According to the authors, VAZ implies that there is a shift in management focus from control over work inputs to work outputs. The implementation of VAZ means that a firm reorganizes its controlling and compensation system to focus on the worker achieving outputs. There is accordingly a reduced focus on the worker's individual tasks and on her physical presence. The study finds that the economic effects of VAZ are generally small and such work practices are associated with a productivity premium of, at most, 5 percent. In contrast to Beckman and Hegedüs (2011) we use the time dimension in the data to aid identification of the impact of VAZ adoption on our dependent variable. We focus on the adoption of VAZ in order to identify our effects. Also - rather than looking at productivity - we look at innovation activity, which is a highly uncertain task in a firm. Accordingly, innovation (due to its uncertain nature), may benefit proportionately more than productivity from the adoption of VAZ work rules.

\section{Data Description}

Our data comes from the IAB Establishment Panel, a representative annual survey of approximately 16,000 plants located in Germany. The survey is undertaken annually by the

\footnotetext{
${ }^{6}$ Bloom et al. (2013) explore the idea of 'trust' by using data from the World Values Survey (WVS) where the question was asked 'Generally speaking, would you say that most people can be trusted, or that you can't be too careful in dealing with people' where the large sample WVS measures trust (are individuals trusted) rather than trustworthiness (would individuals cheat).
} 
Institute for Employment Research (IAB) at the Federal Employment Agency in Nuremberg. It started in 1993 and is ongoing. It covers 1\% of all plants and 7\% of all employment in Germany. The dataset includes information on, e.g., total employment, work arrangements, innovation activity of firms, total sales, and industry (See Appendix 3 for a variables list). ${ }^{7}$

Most importantly from our point of view, since 2006 the survey asks respondents (firm managers) every other year the following question: 'Does your business use a trust-based working hours system (In German: Vertrauensarbeitszeitregelungen) for some or all of the workforce'? The information on trust-based contracts is thus available to us for 2006, 2008 and 2010. Data on innovation (product improvements or process innovation) relates to 2007 2011. Hence, we have a bi-annual snapshot of the implementation of VAZ and returns to VAZ. In what follows, we only use information on firms that did not use VAZ in 2006. Accordingly, we are able to use a research methodology which allows us to observe the innovation performance of firms which adopt VAZ contracts (Adopters) and compare their innovation performance with firms which do not implement such contracts (non-Adopters). The focus on such 'Adopters' vs. 'Non-adopters' (and disregarding all 'Continuous users') allows us to eliminate one aspect of heterogeneity in terms of differences between firms that consistently use VAZ and those that do not. This aids identification of a causal effect of VAZ adoption on innovation.

Specifically, we define two cohorts of firms. For the first cohort of firms (cohort 1), we use the information in 2006 and 2008 to generate a variable indicating the adoption of VAZ workpractices which is equal to one if a firm does not use any trust-based contracts in 2006 but does so in 2008. Our control group is made up of firms which report zeros for VAZ in 2006 and 2008; firms that use VAZ in both 2006 and 2008 are dropped from the analysis. For this first cohort, the outcome variable (innovation) is measured in 2009.

Analogously, we also define a second cohort of firms (cohort 2) where the switching dummy is based on information in 2008 and 2010, and then measure innovation in 2011. The resulting variables trust_2008 and trust_2010 capture the adoption of VAZ work-rules by Adopters in 2008 and 2010 respectively.

\footnotetext{
${ }^{7}$ See Kölling (2000) for a detailed description of the IAB Establishment Panel.
} 
Turning to our innovation variables, the dataset allows us to measure two different aspects. The first innovation measure captures whether an establishment improved or further developed one of their products. The second innovation measure captures whether the firm improved its production technology or introduced a production technology which was new to the firm.

Other variables that we incorporate in our analysis include logged employment size as a measure of the scale of an establishment, Ingesamt, proxies for the establishment's share of skilled to total workers (measured in four categories), skill_year_1 to skill_year_4, and a dummy whether an establishment implements flexible working time (whether it allows time accounts), zeitkonto. These controls are important in order to identify an effect of trust based working time which does not just capture other related labour relations issues.

Tables 1 and 2 provide some summary statistics on some main firm characteristics for VAZ Adopters and non-Adopters for the two cohorts respectively. Roughly 12 to 15 percent of firms in our analysis adopt VAZ work-practices. We find for both cohorts that VAZ Adopters are, on average, larger, more skill intensive, and more likely to be located in West Germany than non-Adopters. Also, they are more likely to implement product or process innovations, and tend to additionally use time accounts.

\section{Empirical Analysis}

\section{Baseline results}

In order to investigate whether the use of trust-based contracts has an impact on innovation we start off using our Cohort 1. We regress innovation activity in 2009 (time t) on the switching dummy in 2008, as well as other covariates in 2008, as shown in equation (1):

$$
\text { innov }_{\text {it }}=\beta_{1} \text { Adopt_VAZ } Z_{i t-1}+\beta_{2} X_{i t-1}+d_{r}+d_{j}+\varepsilon_{i t}
$$

Here, innov is alternatively defined as a dummy equal to one if the firm has improved products in $t$, or equal to one if it introduced new production processes in $t$, respectively. $\mathrm{X}$ is a vector of firm characteristics including firm size, skill levels, and flexible work time, while $d_{r}$ and $d_{j}$ are dummies for West Germany (r) and a full set of industry dummies (j), 
respectively. Controlling for covariates in t-1 helps alleviating concerns about reverse causality in the innovation - VAZ relationship.

Analogously, we also use data for our Cohort 2 and define a dummy which denotes the adoption of VAZ work-practices based on information in 2008 and 2010, and then measure innovation in 2011. Hence, for Cohort 2 we estimate equation (1) with $t=2011$ and $t-1=$ 2010 accordingly.

Tables 3 and 4 present the results from estimating equation (1) for both types of innovation performance using OLS for Cohort 1 and Cohort 2, respectively. These clearly show a positive association between VAZ adoption and the two types of innovation, product and process innovation. Columns (1) and (4) in both tables report simple regressions of the two alternative innovation variables on the adoption dummy, not controlling for any other firm level covariates. Columns (2) and (5) add a variable controlling for the use of flexible work arrangements (time accounts). This allows us to be more confident that our VAZ switching variable does not merely reflect the use of time flexibility - time accounts - but that trustbased work arrangements impact on innovation even when controlling for the use of time flexibility. Columns (3) and (6) add further firm level controls. The coefficient size for VAZ adoption is somewhat reduced following this, but it remains highly statistically significant.

What is the economic meaning of the coefficients? From the descriptive information in Tables 1 and 2 we can see that the overall probability of conducting product innovation is roughly 35 percent in 2009. The coefficient in column (3) of Table 3 (0.13) implies that the conditional probability of product innovation is, on average, about 13 percent higher in firms switching into VAZ than in firms without. This shows that this effect is not only statistically significant, but also economically relevant. The coefficients for process innovation are similar in terms of sign and significance, but slightly lower terms of magnitude, to the coefficients for product innovation.

One concern with the analysis thus far is that, if the adoption of VAZ is a services sector phenomenon (if manufacturing employees are typically 'tied to' fixed equipment, working times and procedures), we might not expect any, or only reduced effects for manufacturing sector firms which adopt VAZ. The IAB data contains proportionately more firms active in the service sector than in manufacturing; only about 1 in every 4 firms is engaged in the 
manufacturing sector (see Appendix 4). We, therefore, report in columns 4 and 8 in Tables 3 and 4 results of estimations using data for the subsample of manufacturing establishments only. The impact on innovation (product and process) is generally positive but statistically insignificant for the manufacturing subsamples. The reduced result for manufacturing firms may be a consequence of the reduced scope for worker autonomy in manufacturing. Alternatively, it may be a consequence of the significant sample attrition, when all services firms are removed. To maintain the sample size we revert to using the full sample of establishments in what follows.

\section{Propensity score matching}

Our identifying assumption thus far is that, conditional on the covariates in the model, switching into VAZ is uncorrelated with $\varepsilon_{\text {it }}$. This assumption would be undermined if there were reverse causality or unobserved third factors that are driving the correlation between innovation and VAZ-switch. We would argue that the first issue, reverse causality, may not be that important, as we define covariates in t-1. Moreover, and perhaps more importantly, it may be unlikely that the decision to improve products or processes may lead firms to overhaul their whole human resources strategy and implement trust-based work contracts.

What is more likely is that unobserved third factors are driving the observed correlation. For example, it might be that firms with higher technology are both more likely to adopt flexible work practices as well as to introduce innovation. ${ }^{8}$ In order to deal with this, we control for observable aspects of firm heterogeneity (size, skill intensity, time flexibility) on the right hand side of equation (1). Furthermore, we introduce industry dummies, which control for the technology intensity, or other relevant unobservable characteristics of industries using industry dummies. Nevertheless, we also implement an alternative estimation strategy, namely, Propensity Score Matching.

In a nutshell, the purpose of matching is to pair each firm which adopts VAZ with comparable firms that do not, on the basis of some observable variables. In this way, the control group of non-Adopters can be studied to generate the counterfactual for the VAZ-Adopters. Under the matching assumptions, the only difference between the treated (Adopters) and control (Nonadopters) group is the use of VAZ and, hence, one can evaluate the effect of VAZ adoption on

\footnotetext{
${ }^{8}$ For example, Bresnahan et al. (2002) show that new management practices and IT use are correlated.
} 
innovation by estimating the difference in the innovation performance between the treated group and the matched control group. One crucial assumption of this approach is that of conditional independence, i.e., controlling for observables, the selection into the VAZAdopter group is random. Propensity Score Matching techniques have been quite popular in the recent applied econometrics literature, we therefore refrain from going into detail about the methodology here. ${ }^{9}$

In order to implement the PSM approach, we first estimate the probability (or propensity score) of firm $i$ implementing VAZ using a probit model

$$
P\left(\text { Adopt }_{-} V A Z_{i t}=1\right)=F\left(X_{i t-1}\right)
$$

where $X$ is a vector of covariates observed in the time period before VAZ. In our view, the most crucial variables that we include in our covariate vector $\mathrm{X}$ are dummies for whether or not a firm conducted product or process innovation in $t-1$. By conditioning on past innovation activity we allow into our treatment and control groups only firms that are similar in terms of past innovation activity, and then see whether switching into VAZ has any additional impact on their innovation activity after switching. In order to also take other characteristics into account, the vector $X$ furthermore consists of the levels (in $t-1$ ) of establishment size (proxied here by employment), a relative skill measure, In_skill_rel, a dummy for time accounts to control for flexible work time, and a dummy variable indicating whether or not a plant is located in West Germany. ${ }^{10}$

Now let $p_{i}$ denote the predicted probability of switching into VAZ for firm $i$ in the group of VAZ users (say group A) and let $p_{j}$ denote the predicted probability of VAZ for firm $j$ in the control group (say group C). Then, following Heckman et al (1997), the matching estimator is defined as follows

\footnotetext{
${ }^{9}$ See, for example, Imbens (2004) for an excellent survey of matching methods. For some examples see Görg, Henry and Strobl (2008), Arnold and Javorcik (2009).

${ }^{10}$ In order to control for sectoral heterogeneity we define the employment size and skills share relative to the sectoral average. More precisely, employment size is measured as 'Logged Differences in the Firm's Employment Size to the Average Employment Size for the Firm's Sector'. The same convention was applied with the skills measure, which reported the share of skilled to non-skilled workers. We use these definitions as it is, unfortunately, not possible to include sectoral dummy variables in the selection probit because the small number of observations in some cells prevented the Adoptor and non-Adopter groups from balancing.
} 


$$
\delta=\sum_{i \in A}\left(y_{i}-\sum_{j \in C} g\left(p_{i}, p_{j}\right) y_{j}\right) .
$$

where $y$ is innovation activity in the treated (i) and control group firms (j) in t. g(.) is a function assigning the weights to be placed on the comparison firm $j$ while constructing the counterfactual for acquired firm $i$.

\section{Balancing VAZ Adopting firms with VAZ non-Adopters}

The first part of Table 5 ('VAZ Adoption') reports the results from the estimation of the selection probit for the two cohorts of establishments. The sign and direction of the covariates are broadly in line with predictions. Firms are more likely to adopt trust-based work rules if they reported a product or process innovation in the previous year. Hence, it is necessary to control for the lagged innovation capability of firms in our sample. Otherwise, if we do not match on innovative capability, we get a biased impression of the role of VAZ adoption on the firm's innovation rates in the following year. Firms which are smaller, relative to other firms in their sector are more likely to adopt trust-based work rules. This may suggest that costs of implementing VAZ are increasing with the number of people involved in groups that work together to achieve the firm's objective. It might also indicate that smaller firms need to improve their competitive position and use trust-based rules defensively to improve their position. Interestingly, as the share of skilled workers increases - relative to the skilled share for firms operating in the same industry - the likelihood that the firm adopts trust-based rules falls. This finding appears to be counter-intuitive at a first glance. However, if the adoption of trust-based rules is a defensive measure - designed to improve the competitive position of weaker firms - it is likely that firms which are falling behind the average values for their sector in terms size and skills share, may implement such rules to strengthen their competitive position.

We generate the propensity scores as predicted values from the probit regression. Figures 1 and 2 illustrate the distribution of the estimated propensity scores for the firms in the two cohorts. It shows that, conditional on the covariates, Adopters are more likely, ex ante, to be classified by the first stage regression probit as belonging to the Adopter group (the distribution of Adopter firms is skewed to the right). This right skew for Adopter firms confirms the need to balance the propensity scores for the Adopter and non-Adopter firms. In 
an iterative procedure, the propensity score procedure, assigns the Adopters and non-Adopters to blocks of establishments. Within these blocks, the group averages for size and other attributes of the establishments are checked for statistical equivalence across the two groups.

Applying the common support condition means that the region of the propensity score where treatment and control group firms can be considered equal in terms of observed covariates are considered. For instance, for the 2008 cohort (establishments adopting VAZ in 2008), this meant that only establishments which had between a 3.6 percent and 34.4 percent chance of being categorized as a VAZ-Adopter firm, were considered in the analysis. Firms from the tails of the distribution are thereby excluded.

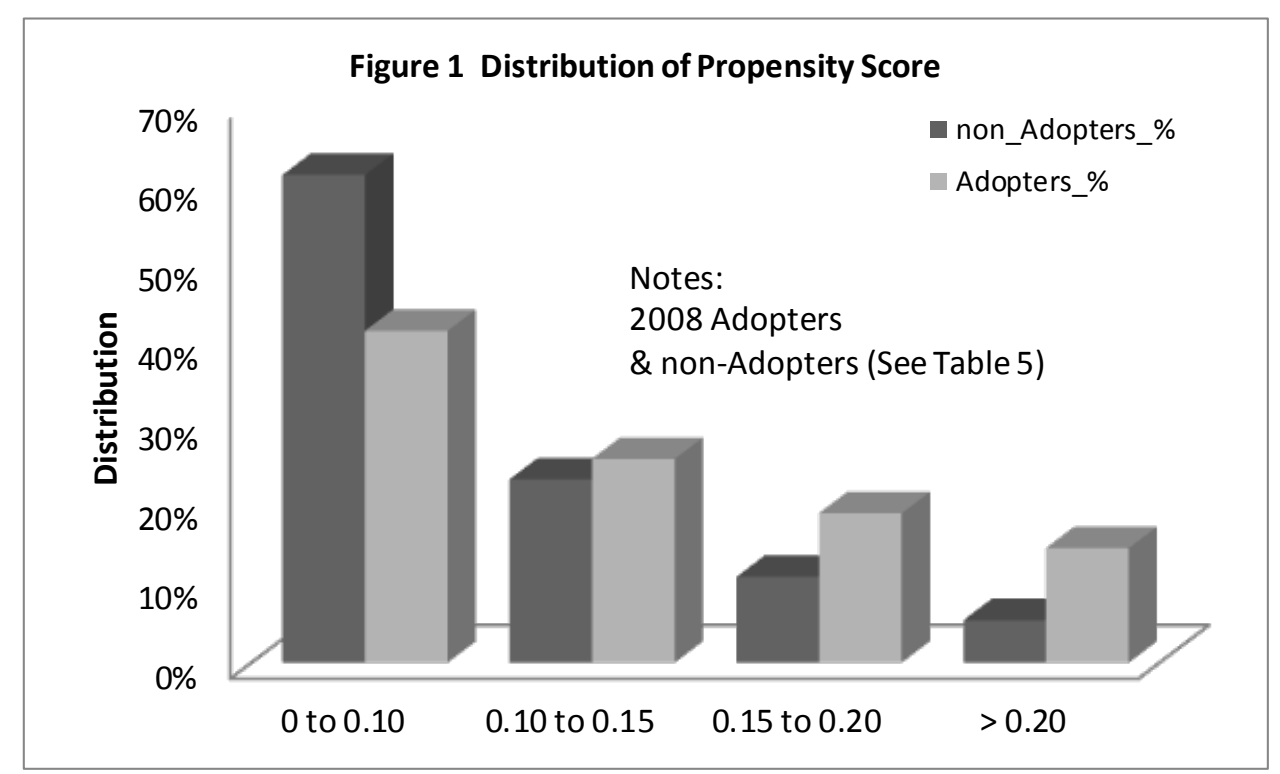




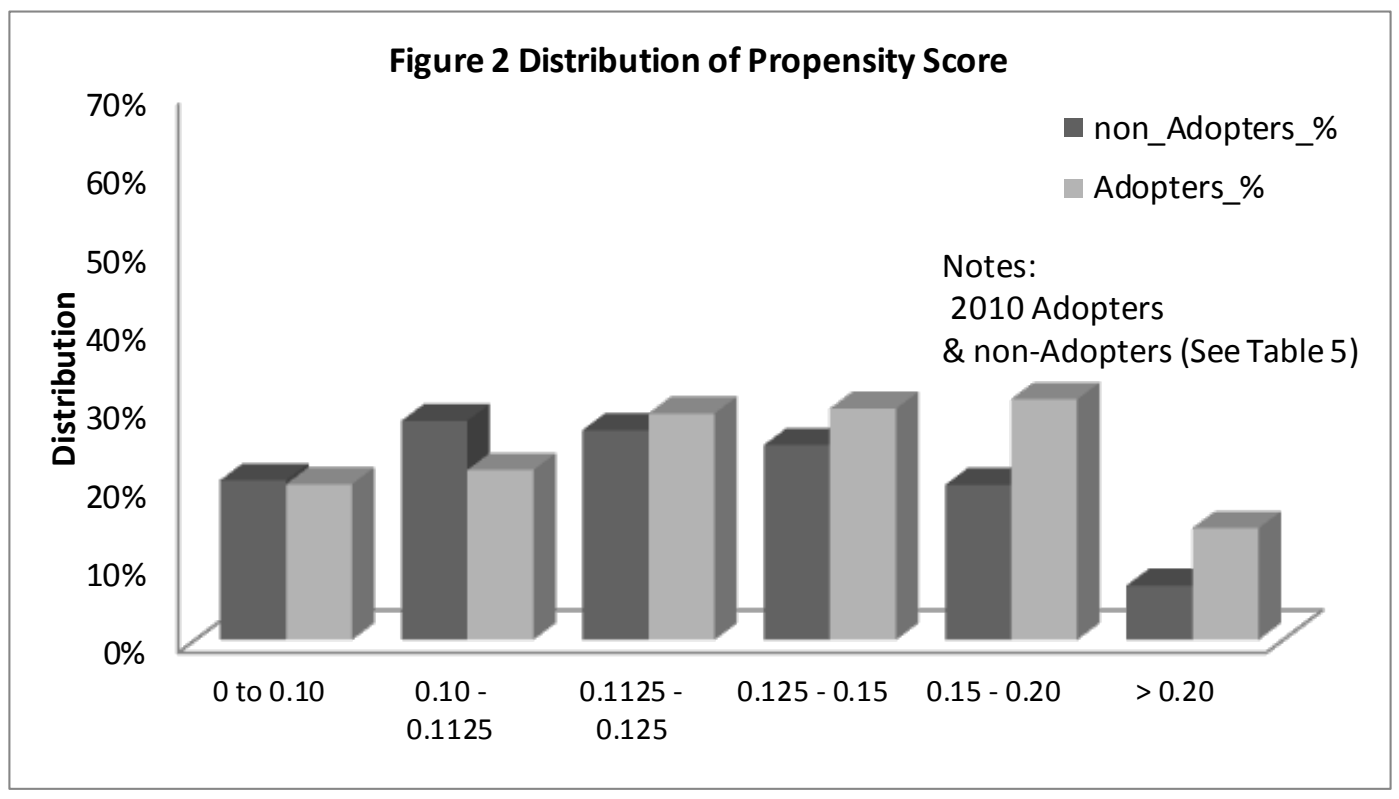

The accompanying STATA pscore procedure indicates that the propensity scores can be balanced across the group of Adopter and non-Adopter firms for both the 2008 and 2010 cohorts. $^{11}$

\section{Premium to VAZ Adoption - PSM}

Following on from this, the second part of Table 5 ('VAZ Adoption and Innovation') reports the results of the PSM approach, i.e., the estimation of equation (3). We only report here the results using our measure of product innovation as outcome variable, as results for process innovation are in all cases statistically insignificant. The results on product innovation are similar in terms of sign, significance and magnitude to those seen in the OLS estimations. Adopting VAZ has a statistically significant and positive impact on innovation activity in the firm using VAZ. The point estimates for establishments adopting trust-based work rules in 2008 and 2010 were 10 percent and 5 percent respectively. In other words, the probability to improve products is 10 and 5 percent higher for firms adopting VAZ than for those that do not in the 2008 and 2010 cohorts respectively. The point estimates for product innovation in the OLS were fairly similar i.e. 13 percent and 9 percent for the 2008 and 2010 cohorts respectively. Hence, VAZ adoption is associated with an innovation premium for product innovation - in line with our priors.

\footnotetext{
${ }^{11}$ The authors can supply the complete output for the propensity scoring and balancing tests on request.
} 


\section{Robustness checks}

An extension which we considered was whether the results were robust when we instrumented for establishments which adopted trust-based rules. ${ }^{12}$ The implementation of the instrumental variables approach relies on the choice of good instruments, which are generally hard to come by. This is why we prefer our PSM approach. We nevertheless searched for instruments which were associated with an establishment's adoption of trust-based rules but which were not associated with the establishment's innovation status, conditional on the covariates included in the model. After careful consideration, two instruments are used in a robustness check.

Our first instrument, access, is based the firm's location choice (See Appendix 3 for variable list). Firms were asked in the 2006 wave of the survey to indicate whether it was important to locate the firm close to the employees' residences because this made the workplace more attractive to workers and helped workers to achieve work/life balance. Accordingly, this variable is related to reduced absenteeism and a reduction in coordination costs among colleagues. It may also indicate the preference of firms to focus on enabling workers to achieve a good work/life balance and may, hence, be correlated with the introduction of trust based work contracts. The second instrument, old, is an instrument measuring the permanence of the firm-employee connection. It is also measured in 2006. The variable may indicate that employers pay attention to worker wellbeing. The intuition behind this instrument is that firms which sought to retain more experienced staff, may be more likely also to adopt trustbased rules.

The results from our IV regression using the above two instruments, show a reduced but nevertheless significant role for the adoption of trust-based rules. The marginal effect is between 3 and 3.5 percent. The results are broadly similar for firms in the 2008 and 2010 cohorts (Appendix 1 and 2).

We also provide some tests for instrument relevance and validity. For the former we provide the Kleibergen-Paap LM test. Here, the null hypothesis is that the estimation is

\footnotetext{
${ }^{12}$ A further extension that we considered was to estimate separately for multi-plant firms having a headquarters, on the assumption that white collar jobs lend themselves more easily to trust-based contracts. No differences were found for such firms, however, this could have been a consequence of the loss in the number of observations for this subset.
} 
underidentified. Higher test-values for the Kleibergen-Paap LM make us more confident that the instruments are relevant, i.e., correlated with the endogenous variable. In our estimations, the instruments work best in the parsimonious model. Once we include measures of size and skills, we cannot reject the Kleibergen-Paap LM. This finding is true for both the 2008 as well as the 2010 cohorts. The Hansen J test provides a test of overidentification restrictions. We cannot reject the validity of these for the 2008 cohort, while the results for the 2010 cohort are less convincing.

Given the problems with the choice of instruments, we take the IV results with a pinch of salt but do note that they point into the same direction as OLS and PSM results. The Propensity Score Matching design allows us to say something about the premium to firms which adopt trust-based rules in a way which deals with selection effects (firms with a certain size, skill and industry profile are more likely to adopt such trust-based rules). We find some evidence that there is indeed an innovation premium for firms which adopt trust-based rules.

\section{Conclusions}

This paper looks at a possible link between firms' use of trust based working hours (VAZ) and innovation activity using firm level data for Germany. The empirical analysis is motivated not only by recent theoretical models in economics that argue that such work arrangement may beneficial if production occurs in an uncertain environment (such as for innovation activity) but also by the management and psychology literatures. The latter studies argue that trust based working time stimulates employee creativity and, thus, impacts positive on creative activities such as innovation.

Results based on propensity score matching techniques comparing ex ante similar firms that adopt VAZ and those that do not, show that firms adopting VAZ tend to be between 11 to 14 percent more likely to improve their products. These results hold when we control for another form of flexible time work arrangements within firms, namely working time accounts. Thus, the positive relationship between the adoption of trust based working hours and innovation seems to be driven by the degree of control and self-management over working days that are transferred to employees, rather than by merely allowing workers increased flexibility. 
Our findings have implications for the vivid policy discussions about flexible work arrangements which may be seen as blurring the lines between professional and private life. Our research shows that such flexible working arrangements benefit firm performance. Accordingly, a return to a more rigid form of work arrangements is likely to inhibit firms from further improving product quality. 


\section{References}

Aghion, P., N. Bloom, R. Blundell, R. Griffith, and P. Howitt, 2005, "Competition and Innovation: An Inverted U Relationship”, Quarterly Journal of Economics, 120 (2), pp. 701728.

Amabile, T.M., and J.S. Mueller. 2008, "Studying creativity, its processes, and its antecedents: An exploration of the componential theory of creativity”. in J. Zhou and C.E. Shalley (eds.), Handbook of Organizational Creativity, New York: Lawrence Erlbaum.

Arnold, J.M., and B.S. Javorcik, 2009, "Gifted kids or pushy parents? Foreign direct investment and plant productivity in Indonesia”. Journal of International Economics, 79(1), pp. 42-53.

Arvanitis, S., 2005, “Modes of Labour Flexibility at Firm Level: Are There Any Implications for Performance and Innovation?”. Industrial and Corporate Change, 14(6), pp. 993-1016.

Beckmann, Michael, and Hegedüs, Istvàn, 2011, “Trust-Based Working Time and Organizational Performance: Evidence from German Establishment-Level Panel Data”, Working papers, Faculty of Business and Economics, University of Basel.

Beauregard, Alexandra T., and Lesley C. Henry. 2009. “Making the Link Between Work-Life Balance Practices and Organizational Performance”. Human Resource Management Review, 19 (1), pp. 9-22.

Bloom, N., R. Sadun, and J. van Reenen, 2012, “The organization of firms across countries”, Quarterly Journal of Economics, 127(4), pp. 1663-1705.

Bloom, N., and J. van Reenen, 2010, Human resource management and productivity, NBER Working Paper 16019.

Bloom, Nick, Tobias Kretschmer, and John Van Reenen. 2011. “Are Family-Friendly Workplace Practices a Valuable Firm Resource? ”. Strategic Management Journal, 32 (4), pp. 343-367. 
Bresnahan, T.F., E. Brynjolfsson, and L.M. Hitt. 2002. "Information Technology, Workplace Organization, and the Demand for Skilled Labor: Firm-Level Evidence.” Q.J.E. 117, pp. 339376.

Brown, A., C. Merkl, and D. Snower. 2009, “Globalization and the welfare state: A review of 'Can Germany be saved?' ”, Journal of Economic Literature, 47, pp. 136-158.

Bureau of Labor Statistics. 2005, Workers on flexible shift schedules in 2004 Summary, USDL 05-1198, Washington D.C..

Dessein, W., and T. Santos. 2006, “Adaptive Organizations”, Journal of Political Economy, 114, pp. 956-995.

German Statistical Office. 2012, Qualität der Arbeit, Wiesbaden.

Görg, H., M. Henry, and E. Strobl. 2008, “Grant Support and Exporting Activity”, Review of Economics and Statistics, 90(1), pp. 168-174.

Heckman, J., Ichimura, H., Smith, J., and Todd, P. 1997, "Matching as an Econometric Evaluation Estimator: Evidence from Evaluating a Job Training Programme”, Review of Economic Studies, 64, pp. 605-654.

Imbens, G.W. 2004, "Nonparametric estimation of average treatment effects under exogeneity: A review”, Review of Economics and Statistics 86, pp-4-29.

Institut der deutschen Wirtschaft. 2010, Informationsdienst des Instituts der deutschen Wirtschaft. 36 (16). Köln. Cologne Institute for Economic Research.

Knight, F.H.. 1921, Risk, uncertainty, and profit, Boston.

Konrad, Alison M., and Robert Mangel. 2000, “The Impact of Work-Life Programs on Firm Productivity.” Strategic Management Journal, 21(12), pp. 1225-37. 
Kölling, A.. 2000, “The IAB Establishment Panel”, Journal of Applied Social Science Studies, 120, pp. 291-300.

Scott, S.G., and R. Bruce. 1994, "Determinants of innovative behaviour: A path model of individual innovation in the workplace”, Academy of Management Journal, 37, pp. 580-607.

Shepard III, Edward M., Thomas J. Clifton, and Douglas Kruse. 1996, “Flexible Working Hours and Productivity: Some Evidence from the Pharmaceutical Industry.” Industrial Relations, 35(1), pp. 123-39.

Stavrou, Eleni. 2005, "Flexible Work Bundles and Organizational Competitiveness: A Crossnational Study of the European Work Context.” Journal of Organizational Behavior, 26 (8), pp. 923-47.

Zhou, H., R. Dekker, and A. Kleinknecht. 2011, "Flexible labor and innovation performance: Evidence from longitudinal firm-level data”, Industrial and Corporate Change, 20, pp. 1-28. 


\begin{tabular}{|c|c|c|c|c|c|c|c|c|c|c|}
\hline & & $\begin{array}{l}\text { Product } \\
\text { innov. }\end{array}$ & $\begin{array}{c}\text { Process } \\
\text { innov. }\end{array}$ & $\begin{array}{l}\text { Uses time } \\
\text { accounts }\end{array}$ & Skills & Logged Size & $\begin{array}{c}\text { West } \\
\text { German }\end{array}$ & $\begin{array}{c}\text { Integrate } \\
\text { older } \\
\text { employees }\end{array}$ & $\begin{array}{l}\text { Locate next } \\
\text { to were } \\
\text { employees } \\
\text { live } \\
\text { important }\end{array}$ & $\begin{array}{c}\text { Regional } \\
\text { infrastructure } \\
\text { important }\end{array}$ \\
\hline \multirow{4}{*}{ 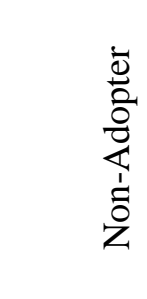 } & Count & 4667 & 4670 & 4768 & 4772 & 4772 & 4772 & 3962 & 4665 & 4658 \\
\hline & Mean & 0.33 & 0.12 & 0.42 & 2.47 & 3.09 & 0.51 & 0.34 & 0.59 & 0.60 \\
\hline & Sd & 0.47 & 0.33 & 0.49 & 1.13 & 1.55 & 0.50 & 0.47 & 0.49 & 0.49 \\
\hline & median & 0.00 & 0.00 & 0.00 & 3.00 & 2.83 & 1.00 & 0.00 & 1.00 & 1.00 \\
\hline \multirow{4}{*}{ 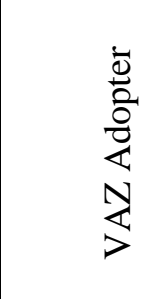 } & Count & 556 & 556 & 573 & 573 & 573 & 573 & 492 & 566 & 566 \\
\hline & Mean & 0.52 & 0.24 & 0.48 & 2.65 & 3.65 & 0.62 & 0.50 & 0.63 & 0.61 \\
\hline & Sd & 0.50 & 0.42 & 0.50 & 1.14 & 1.93 & 0.49 & 0.50 & 0.48 & 0.49 \\
\hline & median & 1.00 & 0.00 & 0.00 & 3.00 & 3.47 & 1.00 & 1.00 & 1.00 & 1.00 \\
\hline \multirow{4}{*}{ 胥 } & Count & 5223 & 5226 & 5341 & 5345 & 5345 & 5345 & 4454 & 5231 & 5224 \\
\hline & Mean & 0.35 & 0.14 & 0.43 & 2.49 & 3.15 & 0.52 & 0.36 & 0.60 & 0.60 \\
\hline & Sd & 0.48 & 0.34 & 0.50 & 1.14 & 1.61 & 0.50 & 0.48 & 0.49 & 0.49 \\
\hline & median & 0.00 & 0.00 & 0.00 & 3.00 & 2.89 & 1.00 & 0.00 & 1.00 & 1.00 \\
\hline
\end{tabular}




\begin{tabular}{|c|c|c|c|c|c|c|c|c|c|c|}
\hline & & $\begin{array}{l}\text { Product } \\
\text { innov. }\end{array}$ & $\begin{array}{c}\text { Process } \\
\text { innov. }\end{array}$ & $\begin{array}{l}\text { Uses time } \\
\text { accounts }\end{array}$ & Skill & Logged Size & $\begin{array}{c}\text { West } \\
\text { German }\end{array}$ & $\begin{array}{c}\text { Integrate } \\
\text { older } \\
\text { employees }\end{array}$ & $\begin{array}{l}\text { Locate next } \\
\text { to were } \\
\text { employees } \\
\text { live } \\
\text { important }\end{array}$ & $\begin{array}{c}\text { Regional } \\
\text { infrastructure } \\
\text { important }\end{array}$ \\
\hline \multirow{4}{*}{ 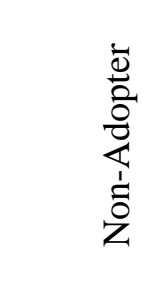 } & Count & 4186 & 4191 & 4765 & 4772 & 4772 & 4772 & 3962 & 1614 & 4665 \\
\hline & Mean & 0.31 & 0.12 & 0.45 & 2.47 & 3.09 & 0.51 & 0.34 & 0.26 & 0.59 \\
\hline & Sd & 0.46 & 0.32 & 0.50 & 1.13 & 1.55 & 0.50 & 0.47 & 0.44 & 0.49 \\
\hline & median & 0.00 & 0.00 & 0.00 & 3.00 & 2.83 & 1.00 & 0.00 & 0.00 & 1.00 \\
\hline \multirow{4}{*}{ 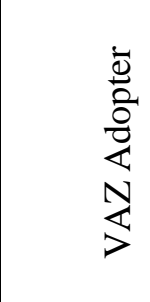 } & Count & 645 & 645 & 720 & 722 & 722 & 722 & 598 & 309 & 711 \\
\hline & Mean & 0.42 & 0.18 & 0.52 & 2.54 & 3.36 & 0.54 & 0.43 & 0.23 & 0.59 \\
\hline & $\mathrm{Sd}$ & 0.49 & 0.39 & 0.50 & 1.16 & 1.77 & 0.50 & 0.50 & 0.42 & 0.49 \\
\hline & median & 0.00 & 0.00 & 1.00 & 3.00 & 3.14 & 1.00 & 0.00 & 0.00 & 1.00 \\
\hline \multirow{4}{*}{$\underset{0}{\tilde{0}}$} & Count & 4831 & 4836 & 5485 & 5494 & 5494 & 5494 & 4560 & 1923 & 5376 \\
\hline & Mean & 0.32 & 0.13 & 0.46 & 2.48 & 3.13 & 0.51 & 0.35 & 0.25 & 0.59 \\
\hline & $\mathrm{Sd}$ & 0.47 & 0.33 & 0.50 & 1.14 & 1.59 & 0.50 & 0.48 & 0.44 & 0.49 \\
\hline & median & 0.00 & 0.00 & 0.00 & 3.00 & 2.83 & 1.00 & 0.00 & 0.00 & 1.00 \\
\hline
\end{tabular}




\begin{tabular}{|c|c|c|c|c|c|c|c|c|}
\hline \multirow[b]{2}{*}{ Variable } & \multicolumn{4}{|c|}{$\mathrm{y}:$ product innovation } & \multicolumn{4}{|c|}{$\mathrm{y}$ : process innovation } \\
\hline & (1) & (2) & (3) & $\begin{array}{c}\text { (4) } \\
\text { Manuf } \\
\text { only }\end{array}$ & (5) & (6) & (7) & $\begin{array}{c}(8) \\
\text { Manuf } \\
\text { only }\end{array}$ \\
\hline \multirow[t]{2}{*}{ VAZ Adoption } & $0.17 * * *$ & $0.16^{* * *}$ & $0.13^{* * *}$ & 0.04 & $0.10 * * *$ & $0.10 * * *$ & $0.08 * * *$ & $0.07 *$ \\
\hline & 0.02 & 0.02 & 0.02 & 0.04 & 0.02 & 0.02 & 0.02 & 0.04 \\
\hline \multirow[t]{2}{*}{ Has time accounts } & & $0.16^{* * *}$ & $0.06^{* * *}$ & $0.05 *$ & & $0.10^{* * *}$ & $0.04^{* * *}$ & $0.04 * *$ \\
\hline & & 0.01 & 0.01 & 0.03 & & 0.01 & 0.01 & 0.02 \\
\hline \multirow[t]{2}{*}{ Logged emp. size 2008} & & & $0.07 * * *$ & $0.10^{* * *}$ & & & $0.05^{* * *}$ & $0.08 * * *$ \\
\hline & & & 0.00 & 0.01 & & & 0.00 & 0.01 \\
\hline \multirow[t]{2}{*}{2008 west } & & & $0.10 * * *$ & $0.06^{* *}$ & & & $0.02 * *$ & 0.01 \\
\hline & & & 0.01 & 0.03 & & & 0.01 & 0.02 \\
\hline \multirow[t]{2}{*}{ q2:\%skilled/non-skilled emp } & & & -0.01 & 0.03 & & & -0.02 & -0.04 \\
\hline & & & 0.02 & 0.03 & & & 0.01 & 0.03 \\
\hline \multirow[t]{2}{*}{ q3:\%skilled/non-skilled emp } & & & 0.02 & 0 & & & -0.01 & -0.02 \\
\hline & & & 0.02 & 0.03 & & & 0.01 & 0.03 \\
\hline \multirow[t]{2}{*}{ q4:\%skilled/non-skilled emp } & & & -0.01 & -0.02 & & & -0.01 & -0.04 \\
\hline & & & 0.02 & 0.04 & & & 0.01 & 0.03 \\
\hline Sector dummies & yes & yes & yes & yes & yes & yes & yes & yes \\
\hline \multirow[t]{2}{*}{ Constant } & $0.24 * * *$ & $0.15^{* * *}$ & $-0.11 * * *$ & -0.08 & $0.13 * * *$ & $0.07^{* * *}$ & $-0.09 * * *$ & -0.14 \\
\hline & 0.02 & 0.02 & 0.03 & 0.07 & 0.01 & 0.02 & 0.02 & 0.05 \\
\hline $\mathrm{N}$ & 5223 & 5219 & 5219 & 1656 & 5226 & 5222 & 5222 & 1662 \\
\hline mss & 100 & 128 & 183 & 84 & 35 & 47 & 70 & 43 \\
\hline rss & 1093 & 1065 & 1010 & 327 & 579 & 566 & 544 & 218 \\
\hline Adjusted R-squared & 0.08 & 0.10 & 0.15 & 0.19 & 0.05 & 0.07 & 0.11 & 0.15 \\
\hline $\mathrm{F}$ & 13.9 & 18.8 & 27.1 & & 6.7 & 8.9 & 11.5 & \\
\hline ll & -3327 & -3257 & 445232 & -1007 & -1664 & -1609 & -1503 & -671 \\
\hline ll_0 & -3555 & -3553 & -3553 & -1195 & -1817 & -1818 & -1818 & -819 \\
\hline
\end{tabular}




\begin{tabular}{|c|c|c|c|c|c|c|c|c|}
\hline & \multicolumn{4}{|c|}{ y: product innovation } & \multicolumn{4}{|c|}{$\mathrm{y}:$ process innovation } \\
\hline & $(1)$ & $(2)$ & (3) & $\begin{array}{c}\text { (4) } \\
\text { Manuf } \\
\text { only }\end{array}$ & (5) & (6) & (7) & $\begin{array}{c}\text { (8) } \\
\text { Manuf } \\
\text { only }\end{array}$ \\
\hline \multirow[t]{2}{*}{ VAZ Adoption } & $0.11^{* * *}$ & $0.10 * * *$ & $0.09 * * *$ & 0.10 & $0.07 * * *$ & $0.06 * * *$ & $0.05^{* * *}$ & 0.10 \\
\hline & 0.02 & 0.02 & 0.02 & 0.04 & 0.02 & 0.02 & 0.02 & 0.04 \\
\hline \multirow[t]{2}{*}{ Has time accounts } & & $0.16^{* * *}$ & $0.06^{* * *}$ & 0.05 & & $0.09 * * *$ & $0.03^{* * *}$ & 0.01 \\
\hline & & 0.01 & 0.02 & 0.03 & & 0.01 & 0.01 & 0.02 \\
\hline \multirow[t]{2}{*}{ Logged emp. size 2008} & & & $0.06 * * *$ & 0.09 & & & $0.05^{* * *}$ & $0.08 * * *$ \\
\hline & & & 0.00 & 0.01 & & & 0.00 & 0.01 \\
\hline \multirow[t]{2}{*}{2008 west } & & & $0.09 * * *$ & 0.13 & & & $0.04 * * *$ & $0.04 *$ \\
\hline & & & 0.01 & 0.03 & & & 0.01 & 0.02 \\
\hline \multirow[t]{2}{*}{ q2:\%skilled/non-skilled emp } & & & 0.02 & 0.04 & & & 0.00 & 0 \\
\hline & & & 0.02 & 0.03 & & & 0.01 & 0.03 \\
\hline \multirow[t]{2}{*}{ q3:\%skilled/non-skilled emp } & & & $0.06 * * *$ & 0.05 & & & -0.01 & -0.04 \\
\hline & & & 0.02 & 0.03 & & & 0.01 & 0.03 \\
\hline \multirow[t]{2}{*}{ q4:\%skilled/non-skilled emp } & & & $0.08^{* * *}$ & 0.09 & & & 0.01 & -0.04 \\
\hline & & & 0.02 & 0.04 & & & 0.01 & 0.03 \\
\hline Sector dummies & yes & yes & yes & yes & yes & yes & yes & yes \\
\hline \multirow[t]{2}{*}{ Constant } & $0.23^{* * *}$ & $0.13^{* * *}$ & $-0.17 * * *$ & -0.01 & $0.11 * * *$ & $0.06^{* * *}$ & $-0.12 * * *$ & -0.08 \\
\hline & 0.02 & 0.02 & 0.03 & 0.07 & 0.01 & 0.01 & 0.02 & 0.05 \\
\hline $\mathrm{N}$ & 4831 & 4826 & 4826 & 1559 & 4836 & 4832 & 4832 & 1559 \\
\hline mss & 93 & 120 & 171 & 84 & 21 & 30 & 51 & 35 \\
\hline rss & 960 & 932 & 881 & 301 & 513 & 504 & 482 & 199 \\
\hline Adjusted R-squared & 0.08 & 0.11 & 0.16 & 0.20 & 0.03 & 0.05 & 0.09 & 0.13 \\
\hline $\mathrm{F}$ & 13 & 18 & 27 & & 5 & 6 & 9 & \\
\hline $\mathrm{ll}$ & -2950.7 & -2879.1 & -2744.13 & -929.4 & -1434.82 & -1393.68 & -1289.01 & -606.15 \\
\hline ll_0 & -3174.3 & -3171.6 & -3171.6 & -1122.07 & -3174.39 & -1533.6 & -1533.6 & -732.26 \\
\hline
\end{tabular}


Table 5 Innovation Premium for VAZ Adopters: Propensity Score Matching

First Stage: VAZ Adoption (Propensity Score Probit)

\begin{tabular}{|l|c|c|c|c|}
\hline & $\begin{array}{c}2008 \\
\text { Adopters }\end{array}$ & & $\begin{array}{c}2010 \\
\text { Adopters }\end{array}$ & \\
\hline & Coeff. & SE & Coeff. & SE \\
\hline Product innovation (i_i) & $0.27^{* * *}$ & $(0.05)$ & $0.15^{* * *}$ & $(0.05)$ \\
\hline Process innovation (i_p) & $0.24^{* * *}$ & $(0.07)$ & $0.20^{* * *}$ & $(0.07)$ \\
\hline Firm employment size (In_size_rel) & $-0.06^{* * *}$ & $(0.02)$ & $-0.03^{* *}$ & $(0.02)$ \\
\hline Firm is West German (West) & $0.24^{* * *}$ & $(0.05)$ & $0.08^{*}$ & $(0.05)$ \\
\hline Share of skilled workers (ln_skill_rel) & $-0.38^{* *}$ & $(0.16)$ & -0.19 & $(0.14)$ \\
\hline Firm has time accounts (zeitkonto) & -0.06 & $(0.05)$ & -0.03 & $(0.05)$ \\
\hline Constant & $-1.43^{* * *}$ & $(0.06)$ & $-1.19^{* * *}$ & $(0.05)$ \\
\hline & & & & \\
\hline Observations & 5051 & & 5095 & \\
\hline LR chi2(6) & 123.8 & & 44.8 & \\
\hline Prob > chi2 & 0.00 & & 0.00 & \\
\hline Pseudo R2 & 0.04 & & 0.01 & \\
\hline Balancing condition passed & yes & & yes & \\
\hline Number of final blocks & 4 & & 6 & \\
\hline Common support condition & yes & & yes & \\
\hline
\end{tabular}

\begin{tabular}{|l|c|c|}
\hline \multicolumn{3}{|c|}{ Second Stage: VAZ Adoption and Innovation (Kernal Density - Propensity Score Matching) } \\
\hline & 2008 Adopters & 2010 Adopters \\
\hline Adopter Premium & $14 \%$ & $11 \%$ \\
\hline t-value for Difference & 10.1 & 5.0 \\
\hline & & 674 \\
\hline Number of Adopters (Treatment) & 538 & 4420 \\
\hline Number of non-Adopters (Control) & 4486 & 5494 \\
\hline Total number of observations & 5024 & 50 \\
\hline Number of repetitions & 50 & \\
\hline
\end{tabular}

\section{Notes:}

PSM uses Stata 'attk' procedure and uses first-stage estimates from Selection Probit. Cohort 1 introduced VAZ in 2008 and Cohort 2 introduced VAZ in 2010. Covariates lagged by one year.

Significance levels are indicated by * $(10 \%),{ }^{* *}(5 \%), * * *(1 \%)$

Balancing tests available from the authors on request. See also Figures 1 and 2 


\begin{tabular}{|c|c|c|c|c|c|c|}
\hline \multirow[t]{2}{*}{ Variable } & \multicolumn{3}{|c|}{$\mathrm{y}:$ product innovation } & \multicolumn{3}{|c|}{ y: process innovation } \\
\hline & $(1)$ & $(2)$ & (3) & (4) & (5) & (6) \\
\hline \multirow[t]{2}{*}{ Adoption of trust-based rules in 2008} & $3.58 * * *$ & $2.99 * * *$ & $2.22 *$ & $2.47 * * *$ & $2.13^{* * *}$ & 1.92 \\
\hline & 0.75 & 0.68 & 1.25 & 0.53 & 0.5 & 1.04 \\
\hline \multirow[t]{2}{*}{ Has time accounts } & & $0.1 * * *$ & $0.09 * * *$ & & 0.06 & 0.06 \\
\hline & & 0.03 & 0.03 & & 0.02 & 0.03 \\
\hline \multirow[t]{2}{*}{ Logged emp. size } & & & 0.02 & & & 0.01 \\
\hline & & & 0.03 & & & 0.02 \\
\hline \multirow[t]{2}{*}{ Former west-German firm } & & & 0.04 & & & -0.03 \\
\hline & & & 0.04 & & & 0.04 \\
\hline \multirow[t]{2}{*}{ Percentage skilled staff (q2) } & & & -0.01 & & & -0.04 \\
\hline & & & 0.04 & & & 0.03 \\
\hline \multirow[t]{2}{*}{ Percentage skilled staff (q3) } & & & 0.02 & & & -0.03 \\
\hline & & & 0.04 & & & 0.03 \\
\hline \multirow[t]{2}{*}{ Percentage skilled staff (q4) } & & & -0.03 & & & -0.05 \\
\hline & & & 0.05 & & & 0.04 \\
\hline Sector dummies & yes & yes & yes & yes & yes & yes \\
\hline \multirow[t]{2}{*}{ Constant } & -0.06 & -0.07 & -0.09 & -0.09 & -0.09 & -0.07 \\
\hline & 0.09 & 0.07 & 0.06 & 0.06 & 0.05 & 0.06 \\
\hline $\mathrm{N}$ & 4234 & 4232 & 4232 & 4236 & 4234 & 4234 \\
\hline Adjusted R-squared & -4.57 & -3.09 & -1.58 & -4.05 & -2.95 & -2.35 \\
\hline F-statistic & 2.79 & 3.97 & 6.42 & 1.83 & 2.36 & 2.74 \\
\hline Prob > F & 0.00 & 0.00 & 0.00 & 0.00 & 0.00 & 0.00 \\
\hline Underidentification test (Kleibergen-Paap LM ) & 24.3 & 22.0 & 4.2 & 24.4 & 22.0 & 4.3 \\
\hline$\chi^{2} \mathrm{p}$-val & 0.00 & 0.00 & 0.25 & 0.00 & 0.00 & 0.23 \\
\hline Hansen J statistic (overidentification test of all instruments) & 1.99 & 2.63 & 3.81 & 0.01 & 0.01 & 0.04 \\
\hline$\chi^{2} \mathrm{p}$-val & 0.37 & 0.27 & 0.15 & 0.99 & 0.99 & 0.98 \\
\hline
\end{tabular}

Firm Location \& Integration of Older Employees as IV Instruments 


\begin{tabular}{|c|c|c|c|c|c|c|}
\hline \multirow[t]{2}{*}{ Variable } & \multicolumn{3}{|c|}{$\mathrm{y}:$ product innovation } & \multicolumn{3}{|c|}{$\mathrm{y}:$ process innovation } \\
\hline & $(1)$ & $(2)$ & (3) & $(4)$ & (5) & (6) \\
\hline \multirow[t]{2}{*}{ Adoption of trust-based rules in 2010} & $3.57 * * *$ & $2.61 * * *$ & $-1.28 * * *$ & $3.45 * * *$ & $3.11^{* *}$ & 0.62 \\
\hline & 1.26 & 1.06 & 0.94 & 1.29 & 1.32 & 0.81 \\
\hline \multirow[t]{2}{*}{ Has time accounts } & & $0.11^{* * *}$ & $0.06 * * *$ & & 0.03 & $0.03^{*}$ \\
\hline & & 0.04 & 0.02 & & 0.04 & 0.01 \\
\hline \multirow[t]{2}{*}{ Logged emp. size } & & & $0.09 * * *$ & & & $0.04 * * *$ \\
\hline & & & 0.02 & & & 0.01 \\
\hline \multirow[t]{2}{*}{ Former west-German firm } & & & $0.13^{* * *}$ & & & 0.03 \\
\hline & & & 0.03 & & & 0.02 \\
\hline \multirow[t]{2}{*}{ Percentage skilled staff (q2) } & & & 0.01 & & & 0.01 \\
\hline & & & 0.03 & & & 0.02 \\
\hline \multirow[t]{2}{*}{ Percentage skilled staff (q3) } & & & $0.07 * *$ & & & -0.02 \\
\hline & & & 0.04 & & & 0.02 \\
\hline \multirow[t]{2}{*}{ Percentage skilled staff (q4) } & & & $0.09 * * *$ & & & 0.01 \\
\hline & & & 0.03 & & & 0.02 \\
\hline Sector dummies & yes & yes & yes & yes & yes & yes \\
\hline \multirow[t]{2}{*}{ Constant } & -0.24 & -0.18 & -0.11 & $-0.35^{*}$ & $-0.32 *$ & $-0.17 * * *$ \\
\hline & 0.18 & 0.14 & 0.07 & 0.18 & 0.18 & 0.05 \\
\hline $\mathrm{N}$ & 3900 & 3898 & 3898 & 3922 & 3920 & 3920 \\
\hline Adjusted R-squared & -5.96 & -3.04 & -0.78 & -10.88 & -8.75 & -0.22 \\
\hline $\mathrm{F}$ & 2.01 & 3.63 & 10.52 & 0.61 & 0.79 & 6.23 \\
\hline Prob $>$ F & 0.00 & 0.00 & 0.00 & 0.96 & 0.81 & 0.00 \\
\hline Underidentification test (Kleibergen-Paap LM ) & 8.81 & 7.29 & 3.98 & 7.66 & 6.05 & 2.01 \\
\hline$\chi^{2} \mathrm{p}$-val & 0.03 & 0.06 & 0.26 & 0.02 & 0.05 & 0.37 \\
\hline Hansen J statistic (overidentification test of all instruments) & 11.26 & 15.04 & 5.95 & 1.74 & 1.81 & 6.62 \\
\hline$\chi^{2} \mathrm{p}$-val & 0.00 & 0.00 & 0.05 & 0.19 & 0.18 & 0.01 \\
\hline
\end{tabular}

Firm Location \& Integration of Older Employees as IV 
Appendix 3 List of variables

\begin{tabular}{|c|c|c|}
\hline Variable & Label & Description \\
\hline employee skill categories & |skill_2010_1 - skill_2010_4 & Skills quartiles (skilled to total employees derived (from bea_qual \& bea_tot) \\
\hline employee skill (sector difference) & ln_skill_rel & Share of skilled to total employees (difference from sector average) \\
\hline employment size (sector difference) & ln_size_rel & Employment size (difference from sector average) \\
\hline instrument_access & access & $\begin{array}{l}\text { From q13 of the } 2006 \text { IAB Betriebspanel survey. employer notes that the attractiveness } \\
\text { of the work location is important for work/life balance. used as instrument in 2SLS }\end{array}$ \\
\hline instrument_single & single & Organization form is a single-plant (i.e not separate from HQ) \\
\hline process innovation & i_p & New procedures which improved production processes \\
\hline product innovation & i_i & Improved existing product \\
\hline $\mathrm{R} \& \mathrm{D}$ & rd_yes & R\&D workers employed in-house (yes| no) \\
\hline time-accounts dummy & zeitkonto* & $\begin{array}{l}\text { Firm has time accounts (check-in and check-out system used to monitor employees on } \\
\text { flexitime) }\end{array}$ \\
\hline trust & trust__ & Trust-based working arrangments (adjusted for missings) \\
\hline trust-rules adopter (in 2008) & trust_2008 & Firm adopts trust-based rules (VAZ) in 2008 \\
\hline trust-rules adopter (in 2010) & trust_2010 & Firm adopts trust-based rules (VAZ) in 2010 \\
\hline
\end{tabular}


Appendix 4 Composition of sample

\begin{tabular}{|c|c|c|c|}
\hline & No. & $\%$ & Cum. \% \\
\hline Agriculture & 89 & 3 & 3 \\
\hline Mining & 44 & 2 & 5 \\
\hline Food & 72 & 2 & 7 \\
\hline Textiles & 30 & 1 & 8 \\
\hline Paper and Printing & 40 & 1 & 9 \\
\hline Wood manufacturers & 60 & 2 & 12 \\
\hline Chemical industry & 32 & 1 & 13 \\
\hline Rubber and Synthetics & 35 & 1 & 14 \\
\hline Stone and Ceramics & 49 & 2 & 16 \\
\hline Metalwork & 48 & 2 & 17 \\
\hline Recycling & 11 & 0 & 18 \\
\hline Steel manufactures & 91 & 3 & 21 \\
\hline Industrial machinery & 106 & 4 & 24 \\
\hline Transport vehicles & 19 & 1 & 25 \\
\hline Other vehicles & 10 & 0 & 25 \\
\hline Electronics & 44 & 2 & 27 \\
\hline Instrumentation & 52 & 2 & 29 \\
\hline Jewellery & 36 & 1 & 30 \\
\hline Contruction (building) & 106 & 4 & 33 \\
\hline Contruction (other) & 154 & 5 & 39 \\
\hline Truck Maintenance and Petrol Retail & 100 & 3 & 42 \\
\hline Wholesale & 108 & 4 & 46 \\
\hline Retail & 209 & 7 & 53 \\
\hline Transport & 94 & 3 & 56 \\
\hline Media & 8 & 0 & 57 \\
\hline Credit and Finance & 48 & 2 & 58 \\
\hline Insurance & 27 & 1 & 59 \\
\hline Computer Services & 31 & 1 & 60 \\
\hline $\mathrm{R} \& \mathrm{D}$ & 35 & 1 & 61 \\
\hline Legal and Advertising & 87 & 3 & 64 \\
\hline Real Estate & 55 & 2 & 66 \\
\hline Rental & 107 & 4 & 70 \\
\hline Hospitality & 109 & 4 & 74 \\
\hline Education & 119 & 4 & 78 \\
\hline Health & 256 & 9 & 87 \\
\hline Hygiene & 14 & 0 & 87 \\
\hline Culture and Sport & 39 & 1 & 88 \\
\hline Other Services & 75 & 3 & 91 \\
\hline Miscellaneous & 78 & 3 & 94 \\
\hline Public Administration & 182 & 6 & 100 \\
\hline
\end{tabular}

